\title{
Comparison of selected local honey with Manuka honey based on their nutritional and antioxidant properties
}

\author{
${ }^{1}$ Zae, T.K., ${ }^{1,2,3^{*}}$ Azlan, A., ${ }^{1}$ Abu Bakar Sajak, A., ${ }^{1}$ Hock, E.K., ${ }^{4}$ Nyuk, L.C., ${ }^{5}$ Md Noh, M.F. \\ and ${ }^{5}$ Mustafa Khalid, N. \\ ${ }^{1}$ Department of Nutrition and Dietetics, Faculty of Medicine and Health Sciences, Universiti Putra \\ Malaysia, UPM Serdang, 43400 Selangor, Malaysia \\ ${ }^{2}$ Research Centre of Excellence for Nutrition and Non-Communicable Diseases, Faculty of Medicine and \\ Health Sciences, Universiti Putra Malaysia, UPM Serdang, 43400 Selangor, Malaysia \\ ${ }^{3}$ Halal Products Research Institute, Universiti Putra Malaysia, 43400 UPM Serdang, Selangor \\ ${ }^{4}$ Department of Process and Food Engineering, Faculty of Engineering, Universiti Putra Malaysia, UPM \\ Serdang, 43400 Selangor, Malaysia \\ ${ }^{5}$ Nutrition, Metabolism and Cardiovascular Research Centre, Institute for Medical Research, National \\ Institute of Health Complex, Level 3, Block C6, Jln. Setia Murni U13/52, Seksyen U13 Setia Alam, 40170
}

Selangor, Malaysia

\section{Article history:}

Received: 16 August 2019

Received in revised form: 4

November 2019

Accepted: 31 January 2020

Available Online: 10

February 2020

\section{Keywords:}

Antioxidant activity,

Malaysian raw honey,

Proximate composition,

Total phenolic content

DOI:

https://doi.org/10.26656/fr.2017.4(S1).S12

\begin{abstract}
This study aimed to determine and compare the proximate composition, sugars content and antioxidant properties of selected Malaysian raw honey (Tualang, Gelam, Kelulut, Wild, and Pineapple) with Manuka honey. Proximate analysis (energy, carbohydrate, protein, fat, ash, moisture and total dietary fibre), sugar analysis (fructose, sucrose, glucose and maltose), total phenolic content (TPC) and antioxidant analysis (DPPH radical scavenging activity and linoleic acid oxidation assay) were conducted on the honey samples. The proximate analysis and sugar analysis results for all honeys were within Codex Alimentarius Commission guidelines. In general, Malaysian honeys exhibited lower level of carbohydrates $(80.27 \%$ to $82.32 \%)$, energy $(324.18 \mathrm{kcal} / 100 \mathrm{~g}$ to 331.20 $\mathrm{kcal} / 100 \mathrm{~g})$, ash $(0.17 \%$ to $0.28 \%)$ and protein $(0.24 \%$ to $0.26 \%$, except for Gelam $0.45 \%)$ but higher in moisture $(17.07 \%$ to $19.08 \%)$ and fat $(0.10 \%$ to $0.36 \%)$ contents compared to Manuka honey. No significance differences $(\mathrm{P}>0.05)$ was detected in total sugar among the honey samples. Overall, among the selected honeys, Kelulut honey has the highest energy content, lowest moisture level, fat content and fructose level. Meanwhile, Wild honey showed the highest phenolic content and antioxidant activities.
\end{abstract}

\section{Introduction}

The current trends in food and nutrition are based on the concept that healthy alimentation is the premise of a healthy and active body with higher life expectancy. Today, consumers are getting more interested in the beneficial effects of health food. Honey is gaining attention worldwide due to its nutritional and medicinal properties (Bogdanov, 2016). It is a natural sweet substance produced by honey bees, Apis mellifera, from the nectar of plants (blossoms or other plants) or from the secretions of living parts of plants or excretions of plant-sucking insects on the living parts of plants, which honey bees collect, transform by combining with specific substances of their own, deposit, dehydrate, store and leave in the honeycomb to ripen and mature (Codex Alimentarius Commission, 2001).
In the United States, honey has been advocated to be used as a substitute for refined sugars due to its lower glycemic index compared with sucrose (National Honey Board, 2015). Honey not only imparts sweetness but also provides other nutrients such as vitamins and minerals, which improved its nutrient quality (Adenekan et al., 2012). Besides, honey is slightly sweeter than sugars because it contains high fructose content; therefore, a lesser amount of honey can achieve the same sweetness intensity as refined sugar does (National Honey Board, 2015).

Sugar consumption among Malaysians is increasing at an alarming rate. Malaysia is the 8th highest sugar consumer country in the world, and high sugar intake was identified as one of the factors that contribute to the increased prevalence of overweight, obesity and diabetes 
(Consumers Association of Penang, 2011). Based on a survey conducted in Malaysia, the National Health and Morbidity Survey indicated that the prevalence of diabetes, overweight, and obesity increased from $11.6 \%$ to $15.2 \%, 31.6 \%$ to $33.3 \%$, and $16.3 \%$ to $27.3 \%$, respectively from 2006 to 2011 (Institute for Public Health, 2011).

Due to the increasing prevalence of several metabolic diseases, there is a need to educate the public in choosing functional sweetener. Moreover, the beneficial content in honey differs depending on factors such as type of flower, pollinator species and geographical region (Finola et al., 2007). Thus, this study aimed to explore and to compare the nutritional composition and antioxidant properties of selected Malaysian raw honey such as Gelam, Kelulut, Wild, Tualang and Pineapple honey.

\section{Material and methods}

\subsection{Samples}

Table 1. Information on botanical origin/floral types, dominant pollen or nectar and bee species for each type of honey

\begin{tabular}{lccc}
\hline Type of Honey & Botanical & Dominant & Bee species \\
\hline Tualang & Multifloral & None & Apis dorsata \\
Gelam & Monofloral & $\begin{array}{c}\text { Melaleuca } \\
\text { cajuputi }\end{array}$ & Apis dorsata \\
Wild/Borneo & Multifloral & $\begin{array}{c}\text { None } \\
\text { Pineapple }\end{array}$ & Apis cerana \\
Kelulut & Multifloral & $\begin{array}{c}\text { Ananas } \\
\text { comosus }\end{array}$ & Apis mellifera \\
Manuka & Monofloral & $\begin{array}{c}\text { Leptospermum } \\
\text { scoparium }\end{array}$ & Apis mellifera \\
\hline
\end{tabular}

A total of five selected Malaysian raw honey (Tualang, Gelam, Kelulut, Wild, and Pineapple) were purchased from Federal Agricultural Marketing Authority (FAMA) in Selangor, Malaysia, where the officer in FAMA had done the sampling-based their established protocol. The selection of these honeys was based on the feasibilities of the honey to be purchased by consumers in the Malaysian market. Tualang, Gelam, Pineapple and Wild honey are produced by bees from Apis spp. while, Kelulut is produced by stingless bees or known as Trigona spp. (Table 1). Based on botanical origin, Tualang, Wild and Kelulut are multifloral honey (no dominant nectar/pollen from a single plant is found in the honey). In addition, Gelam, Pineapple and Manuka are considered as monofloral honey (a dominant nectar/ pollen from a single plant is found in the honey). In this study, Manuka honey was used for comparison (Agbagwa et al., 2011). The Manuka honey was an organic brand from New Zealand. All the samples were kept at room temperature in the laboratory $\left(25^{\circ} \mathrm{C}\right)$ before further analyses.

\subsection{Determination of proximate composition}

Proximate content, namely moisture, ash, protein, fat, total dietary fibre and total available carbohydrate were determined based on the AOAC Official Method (AOAC International, 2005). All the analyses were performed in three replicates. Moisture content was determined by using an air oven drying method, which is introduced in AOAC Official Method 990.19. Ash content was determined using the dry ashing method (AOAC Official Method 990.11), protein content was determined by the Kjeldahl method (AOAC Official Method 973.48), fat content was determined by the Soxhlet extraction method (AOAC Official Method 2003.06), and total dietary fibre content was determined using the enzymatic-gravimetric method (AOAC Official Method 2001.03). Total available carbohydrate content was determined using the "difference method" (Food and Agriculture Organization, 2015).

Total available carbohydrate content $(\mathrm{g} / 100 \mathrm{~g}$ fresh weight, $\mathrm{FW})=100-[$ Weight in grams $($ protein + fat + water + ash + dietary fiber) in $100 \mathrm{~g}$ honey]

The energy level was calculated by the summation of a gram of carbohydrate multiply by $4 \mathrm{kcal} / \mathrm{g}$, a gram of protein multiply by $4 \mathrm{kcal} / \mathrm{g}$, a gram of dietary fiber multiply by $2 \mathrm{kcal} / \mathrm{g}$, and a gram of fat multiply by 9 $\mathrm{kcal} / \mathrm{g}$ (Whitney and Rolfes, 2008).

Energy level $(\mathrm{kcal} / 100 \mathrm{~g} \mathrm{FW})$ edible portion $=[$ Total available carbohydrate $(\mathrm{g} / 100 \mathrm{~g}) \times 4 \mathrm{kcal} / \mathrm{g}]+$ [Protein $(\mathrm{g} / 100 \mathrm{~g}) \times 4 \mathrm{kcal} / \mathrm{g}]+[$ Total dietary fiber $(\mathrm{g} / 100 \mathrm{~g}) \times 2$ $\mathrm{kcal} / \mathrm{g}]+[$ Fat $(\mathrm{g} / 100 \mathrm{~g}) \times 9 \mathrm{kcal} / \mathrm{g}]$

\subsection{Determination of sugar composition}

Primary sugar contents of samples such as fructose, glucose, sucrose, and maltose were analyzed using a high -performance liquid chromatography (HPLC) system coupled to a refractive index detector. An Xbridge BEH amide column with the dimension of $2.5 \mu \mathrm{m}, 4.6 \mathrm{~mm} \times$ $100 \mathrm{~mm}$ was used for separation of sugars. The column was kept at $40^{\circ} \mathrm{C}$ throughout the analysis. The mobile phase was $75 \%$ acetonitrile in deionized water with a flow rate of $1.0 \mathrm{~mL} / \mathrm{min}$.

About $1.0 \mathrm{~g}$ honey sample was diluted with 50:50 acetonitrile/water and top up to $25 \mathrm{~mL}$. After that, the mixture was filtered by a membrane filter and kept in an amber vial. For HPLC analysis, $20 \mu \mathrm{L}$ of the sample was injected into the HPLC system. Standard sugar solution for each sugar was prepared and diluted to 
concentrations of $0.1,0.2,0.5,0.8$ and $1.0 \%$ for determination of retention time (glucose, fructose, sucrose and maltose). Total sugar content was obtained by the summation of individual sugar, including glucose, fructose, and sucrose.

\subsection{Extraction of antioxidant compounds}

Antioxidant compounds of all honey samples were extracted using $100 \%$ methanol. A $10 \mathrm{~mL}$ honey was added with $20 \mathrm{~mL}$ of methanol and well-mixed by swirling for $1 \mathrm{~min}$. The mixture was stored for a day at $20^{\circ} \mathrm{C}$ for precipitation of sugar. The frozen honey was defrosted and centrifuged at $1000 \mathrm{rpm}$ for removal of sugar. The supernatant (honey extract) was stored at $-20^{\circ}$ $\mathrm{C}$ before analyses.

\subsection{Total phenolic content}

Estimation of total phenolic content (TPC) was performed based on a method by Khoo et al. (2012) with slight modification. The honey extracts $(0.2 \mathrm{~mL}, 100 \mathrm{mg} /$ $\mathrm{mL}$ ) were mixed with $1.5 \mathrm{~mL}$ of Folin-Ciocalteu reagent (previously diluted 10-fold with distilled water) and allowed to stand at room temperature for 5 mins. Then, $1.3 \mathrm{~mL}$ of sodium bicarbonate solution $(60 \mathrm{~g} / \mathrm{L})$ was added to each mixture.

The absorbance of the sample was measured at 750 $\mathrm{nm}$ using a Secomam's RS232 UV-visible spectrophotometer (Cedex, France) after 90-min incubation at room temperature. TPC of the sample was calculated using regression equations from the standard curve of gallic acid $(12.5-200 \mu \mathrm{g} / \mathrm{mL}$ in methanol). The results were expressed as milligrams of GAE per $\mathrm{g}$ of fresh weight $(\mathrm{FW})$. Triplicate determinations were performed for TPC assay.

\subsection{DPPH radical scavenging activity}

Antioxidant capacities of honey samples were evaluated by DPPH radical scavenging assay based on the method of Khoo et al. (2013). Briefly, a $0.2 \mathrm{~mL}$ aliquot of honey extracts $(31.25-500 \mathrm{mg} / \mathrm{mL})$, or reference standard (gallic acid, $0.01-0.125 \mu \mathrm{g} / \mathrm{mL}$ ) were mixed with $0.1 \mathrm{M}$ Tris-HCl buffer $(0.8 \mathrm{~mL}, \mathrm{pH} 7.4)$ and then added to $1.0 \mathrm{~mL}$ of $0.5 \mathrm{mM}$ DPPH in methanol. The mixture was vortexed for $10 \mathrm{~s}$ and left to stand at room temperature in the dark. After $30 \mathrm{~min}$, the absorbance was measured spectrophotometrically at $517 \mathrm{~nm}$. The antioxidant capacities of the samples were calculated based on the following equation.

Antioxidant capacity $(\%)=1-\frac{\text { The absorbance of the sample at } 517 \mathrm{~nm}}{\text { The absorbance of control at } 517 \mathrm{~nm}} \times 100$

\subsection{Linoleic acid oxidation assay}

Inhibition of linoleic acid oxidation was carried out based on a method described by Khoo et al. (2013) with slight modifications. It is mimicking the biological system in scavenging free radicals. The diluted honey extracts $(500 \mathrm{mg} / \mathrm{mL})$ or reference standard (gallic acid, $500 \mu \mathrm{g} / \mathrm{mL})(0.2 \mathrm{~mL})$ were added to $0.026 \mathrm{~mL}$ of linoleic acid solution, $2.0 \mathrm{~mL}$ of methanol $(80 \% \mathrm{v} / \mathrm{v})$ and $1.0 \mathrm{~mL}$ of $0.2 \mathrm{M}$ phosphate buffer saline $(\mathrm{pH} 7.0)$. Then, the mixture was made up to $4.0 \mathrm{~mL}$ with methanol $(80 \% \mathrm{v} /$ v) and incubated at $40^{\circ} \mathrm{C}$ for $20 \mathrm{hrs}$. The inhibition of oxidation was measured as peroxide value applying the thiocyanate method (Yen et al., 2000). After 3 mins of stirring, the absorption was measured at $500 \mathrm{~nm}$. The protective capacity (\%) of honey samples was calculated based on the equation as follows:

Protective capacity $(\%)=1-\frac{\text { The absorbance of the sample at } 20 \mathrm{hrs}}{\text { The absorbance of control at } 20 \mathrm{hrs}} \times 100$ 2.8 Statistical analysis

All the results obtained were expressed as mean \pm standard deviation (SD). The significant difference was set at $P<0.05$. The significant differences in nutrient contents and antioxidant properties between two samples were determined by one-way analysis of variance (ANOVA) and Posthoc multiple comparison test (Tukey HSD) using IBM SPSS version 21.

\section{Results and discussion}

\subsection{Proximate composition}

Proximate compositions of the selected Malaysian raw honey and Manuka honey are depicted in Table 2. The results showed that all the honey contained adequate energy content. Energy contents of all the raw honey ranged from $324.18 \mathrm{kcal} / 100 \mathrm{~g}$ to $352.75 \mathrm{kcal} / 100 \mathrm{~g}$. Among the local honey, Kelulut honey $(331.20 \mathrm{kcal} / 100$ g) possessed the highest energy content, while the least energy content can be found in Wild honey (324.18 $\mathrm{kcal} / 100 \mathrm{~g}$ ). The results obtained were consistent with the previous study by Blasa et al. (2006) and Buba et al. (2013), where they found an average energy content of different honey was in between $303 \mathrm{kcal} / 100 \mathrm{~g}$ to $337.37 \pm 5.84 \mathrm{kcal} / 100 \mathrm{~g}$.

Relative to local honey samples, Manuka honey showed a significantly higher energy content $(352.75 \mathrm{kcal} / 100 \mathrm{~g})$, than all the Malaysian raw honey. The differences in energy content especially Manuka is contributed by the total carbohydrate content. Where Manuka honey had the highest total available carbohydrate $(87.60 \pm 0.04)$ compared to other local honeys (82.32 $\pm 0.06-80.76 \pm 0.04)$. According to Bogdanov et al. (2008), 95\% of carbohydrates in honey mainly consists of fructose and glucose. This statement supports our finding, where the total sugar content (Table 4, which is discussed in the next section) in Manuka was higher $(64.19 \pm 2.69)$ than the local honey 
Table 2. Proximate composition of selected Malaysian raw honey and Manuka honey

\begin{tabular}{lccccccc}
\hline Sample & Moisture $^{\dagger}$ & Ash $^{\dagger}$ & Protein $^{\dagger}$ & Fat $^{\dagger}$ & TDF $^{\dagger}$ & TAC $^{\dagger}$ & Energy $^{\dagger}$ \\
\hline Tualang & $17.95 \pm 0.03^{\mathrm{c}}$ & $0.23 \pm 0.01^{\mathrm{c}}$ & $0.26 \pm 0.01^{\mathrm{c}}$ & $0.18 \pm 0.01^{\mathrm{c}}$ & ND & $81.38 \pm 0.06^{\mathrm{c}}$ & $328.21 \pm 0.13^{\mathrm{d}}$ \\
Gelam & $17.90 \pm 0.04^{\mathrm{c}}$ & $0.28 \pm 0.01^{\mathrm{ab}}$ & $0.45 \pm 0.00^{\mathrm{a}}$ & $0.36 \pm 0.02^{\mathrm{a}}$ & ND & $81.01 \pm 0.08^{\mathrm{d}}$ & $329.13 \pm 0.15^{\mathrm{c}}$ \\
Kelulut & $17.07 \pm 0.05^{\mathrm{d}}$ & $0.27 \pm 0.01^{\mathrm{b}}$ & $0.26 \pm 0.00^{\mathrm{c}}$ & $0.10 \pm 0.01^{\mathrm{d}}$ & ND & $82.32 \pm 0.06^{\mathrm{b}}$ & $331.20 \pm 0.25^{\mathrm{b}}$ \\
Wild & $19.08 \pm 0.03^{\mathrm{a}}$ & $0.17 \pm 0.01^{\mathrm{e}}$ & $0.24 \pm 0.00^{\mathrm{d}}$ & $0.24 \pm 0.01^{\mathrm{b}}$ & ND & $80.27 \pm 0.04^{\mathrm{f}}$ & $324.18 \pm 0.14^{\mathrm{f}}$ \\
Pineapple & $18.63 \pm 0.03^{\mathrm{b}}$ & $0.20 \pm 0.01^{\mathrm{d}}$ & $0.25 \pm 0.00^{\mathrm{cd}}$ & $0.17 \pm 0.01^{\mathrm{c}}$ & ND & $80.76 \pm 0.04^{\mathrm{e}}$ & $325.60 \pm 0.21^{\mathrm{e}}$ \\
Manuka & $11.60 \pm 0.02^{\mathrm{e}}$ & $0.30 \pm 0.01^{\mathrm{a}}$ & $0.43 \pm 0.00^{\mathrm{b}}$ & $0.08 \pm 0.02^{\mathrm{d}}$ & ND & $87.60 \pm 0.04^{\mathrm{a}}$ & $352.75 \pm 0.04^{\mathrm{a}}$ \\
\hline
\end{tabular}

$\dagger$ Moisture, ash, protein, fat total dietary fibre (TDF) and total available carbohydrate (TAC) contents of honey sample are expressed as mean \pm standard deviation of three replications. \$The energy values were obtained by summation method and expressed as kcal/100 g; ND: Not detected. Value in the same columns with different superscript lowercase letters were significantly different $(\mathrm{P}<0.05$, ANOVA, Tukey's HSD)

$(62.76 \pm 0.13-62.70 \pm 0.12)$.

The moisture content of honey is a critical quality parameter as it can influence the flavour, preservation, viscosity, specific weight, crystallization, and palatability, as well as contribute to the development of fermenting microorganisms (Finola et al., 2007; Ajani, 2009). Overall, the moisture contents of Malaysian raw honey ranged from $17.07 \%$ to $19.08 \%$, where the Wild honey contained the highest moisture content (19.08\%). Comparing with Manuka, Manuka showed the lowest moisture content $(11.60 \%)$ compared to other studied honey.

The differences in moisture content in local honey and Manuka is mainly due to climatic factors since Malaysia is a tropical country with high humidity. It is well known that factors such as floral source, harvesting season, degree of honey maturity in the hive, and climatic factors can influence moisture level in honey (Finola et al., 2007). Higher moisture content could lead to undesirable fermentation of honey during storage and result in the formation of ethyl alcohol and carbon dioxide (Moniruzzaman et al., 2013). Then, alcohol produced from fermentation can further oxidize to acetic acid and water, which can increase the acidity and give a sour taste to the honey (Chirife et al., 2006). Therefore, honey with high moisture content can stale easily while honey with low moisture content can promote a longer shelf-life (Ajani, 2009). In the present study, Kelulut honey was expected to have the most extended shelf-life as it contained the lowest moisture content as compared to other Malaysian raw honey.

From the result, the ash contents of all the Malaysian raw honeys ranged from $0.17 \%$ to $0.28 \%$, which within Codex Alimentarius Commission (2001) guidelines for floral honey, which is less or equal to $0.6 \%$. Gelam honey $(0.28 \%)$ showed the highest ash content and lowest ash content can be found in Wild honey $(0.17 \%)$. These findings were consistent with previously reported ash values of some Malaysian raw honey that ranged from $0.19 \%$ to $0.27 \%$ (Chua and Adnan, 2014) and
$0.10 \%$ to $0.30 \%$ (Jaafar et al., 2012). Comparing the ash content with Manuka, Manuka has the highest ash content $(0.30 \%)$ compared to Malaysian honey. This result also similar with the previous study by Kek et al. (2016), where they found Manuka honey possess higher content of ash $(0.31 \pm 0.01 \mathrm{~g} / 100 \mathrm{~g})$ compared to Malaysian local honey (Tualang, Gelam, Pineapple, Borneo and Kelulut).

Determination of ash content is useful for predicting mineral and trace element contents (Bradbear, 2009). High ash content indicates high mineral and trace element content of the honey, and vice versa (Bradbear, 2009). Therefore, among all the honey samples, it was expected that Manuka, which contained the highest ash content, had the highest mineral. Meanwhile, among the local honey, Gelam had the highest mineral content and Wild honey with the lowest ash content had the lowest mineral content.

Fat contents of all the honey ranged from $0.10 \%$ to $0.08 \%$, where Gelam honey $(0.36 \%)$ possessed the highest fat and Manuka honey had the lowest fat content $(0.08 \%)$. This result indicates that Malaysian honey possesses more fat content more than Manuka honey. Generally, honey has been reported in a few studies with little or no fat content (Singh and Bath, 1997; Chua and Adnan, 2014), but minute amount of free fatty acids such as linolenic acids, oleic acids, and palmitic acids were found in white clover honey from New Zealand (Tan et al., 1988). According to Somerville (2005), the fat content of honey mainly came from fatty acids, such as capric, lauric, myristic, linoleic, linolenic acids, which were known to have antimicrobial properties. He also stated that the differences in fat content in honey are due to different nectar sources where honey bees are usually attracted to pollen with higher fat content compared to pollen with lower fat content.

The protein contents of all the honey ranged from $0.24 \%$ to $0.45 \%$. Gelam honey $(0.45 \%)$ showed the highest protein content, followed by Manuka honey $(0.43 \%)$ and the lowest was in Wild honey $(0.24 \%)$. As 
stated earlier, the variation in protein content of the honey samples could be due to the different floral nectars sources and enzymes added by the honey bees (Andrada and Tellería, 2005). During the ripening process of honey, honey bees introduce different enzymes, such as amylase, invertase and glucose oxidase, to help in the regulation of hydrogen peroxide production (Bogdanov et al., 2008). As a result, the protein content of honey is influenced by different enzymes added by the honey bees.

Total dietary fibre content was not detected in all the samples. These findings were consistent with previous studies, where there is no total dietary fibre content has been reported in honey (Buba et al., 2013; Chua and Adnan, 2014; Bogdanov, 2016). According to Murray et al. (2001), honey was considered as low-fibre food in which the carbohydrate content of honey was mainly composed of sugar (glucose, fructose, sucrose) instead of indigestible carbohydrate, and it mainly used as a natural sweetener.

Total nitrogen content of honey can be used as an indication to detect honey frauds due to the addition of carbohydrates when the total nitrogen content was below $0.03 \%$ (Codex Alimentarius Commission, 2001). Besides, the nitrogen content of honey is derived from the proteins and amino acids of pollen or nectars collected (Vit et al., 1994). The total nitrogen contents determined in all honey samples exceeded $0.04 \%$ (Table $3)$. Therefore, they are considered genuine honey.

Table 3. Total nitrogen content of Malaysian raw honey and Manuka honey

\begin{tabular}{cc}
\hline Sample & Total nitrogen content $(\%)$ \\
\hline Tualang & $0.04 \pm 0.00^{\mathrm{b}}$ \\
Gelam & $0.07 \pm 0.00^{\mathrm{a}}$ \\
Kelulut & $0.04 \pm 0.00^{\mathrm{b}}$ \\
Wild & $0.04 \pm 0.00^{\mathrm{c}}$ \\
Pineapple & $0.04 \pm 0.00^{\mathrm{bc}}$ \\
Manuka & $0.07 \pm 0.00^{\mathrm{a}}$ \\
\hline
\end{tabular}

All values are expressed as mean \pm standard deviation of three replications. The value in the same columns with different superscript lowercase letters were significantly different $(\mathrm{P}<0.05$, ANOVA, Tukey's HSD)

\subsection{Sugar content}

In the present study, total sugar in all honey sample ranged from $64.19 \pm 2.69 \%$ to $62.70 \pm 0.12 \%$, with Manuka honey contained the highest total sugar content, followed by Wild honey (Table 4). However, no significant difference $(\mathrm{P}>0.05)$ was detected between the total sugar in the honey samples. The main sugar components in honey are fructose and glucose, followed by maltose and sucrose. Among all the honey samples, Manuka honey showed the highest fructose, summation fructose to glucose, fructose to glucose ratio ( $\mathrm{F} / \mathrm{G}$ ratio) and glucose to water ratio $(\mathrm{G} / \mathrm{W})$ but lower in maltose value compared to local honey.

Previous study conducted by Kek et al. (2016) in Malaysian honey reported fructose and summation fructose to glucose content in Gelam, Tualang, Pineapple and Borneo honey are more or less similar with Manuka. The differences in sugar content in honey are mostly dependent on botanical and geographical regions, and factors such as weather and post-harvest factors such as storage and processing condition (Khalil et al., 2011). In the present study, all the Malaysian raw honey complied with the international standard because the sums of their fructose and glucose contents were $\geq 60 \%$. Therefore, they are considered as good quality honey. Besides, all the honey samples contained a higher amount of fructose than glucose.

Natural honey can be differentiated from commercial invert sugar based on the dominance of fructose over glucose in honey (White and Doner, 1980). Besides, fructose content in honey should also exceed glucose content for good quality honey (Zafar et al., 2008). It is because glucose is less soluble in water than fructose. If the glucose content of honey exceeds fructose content, it tends to crystallise, and it affects its quality (White and Doner, 1980). Glucose/Water (G/W) ratio of Malaysian raw honey was lower than Manuka honey. The low G/W ratio decreases the crystallization rate of sugar. Besides that, Malaysian raw honey is less sweet than Manuka honey because the fructose/glucose $(\mathrm{F} / \mathrm{G})$ ratio is lower than manuka honey (Kamal and Klein, 2011).

\subsection{Total phenolic content}

The presence of phenolic compounds in honey is well documented. Phenolic acids and flavonoid have been considered one of the important biomarkers for botanical origin of the honey. One of the simple tests to determine phenolic content is by using Folin-Ciocalteu assay (Khalil et al., 2011). From the results (Figure 1), the Wild honey had the highest total phenolic content (TPC), followed by Tualang and Gelam, Manuka, Kelulut and lastly, Pineapple honey. Phenolic content in Wild honey is 3-fold higher than Manuka, whilst Tualang and Gelam are 1-fold higher than Manuka. This result indicates that multifloral honey from Apis spp. (Wild and Tualang) has a higher phenolic content compared to monofloral honey in Apis spp. (Gelam, Manuka and Pineapple).

Comparing with the previous study conducted by Khalil et al. (2011) on Malaysian honey, they found that 
Table 4. Sugar composition of selected Malaysian raw honeys and Manuka honey

\begin{tabular}{|c|c|c|c|c|c|c|c|c|}
\hline Sample & Fructose & Glucose & Sucrose & Maltose & Total Sugar & $\begin{array}{c}\text { Fructose }+ \\
\text { Glucose }\end{array}$ & $\begin{array}{c}\text { Fructose/ } \\
\text { Glucose }(\mathrm{F} / \mathrm{G}) \\
\text { ratio }\end{array}$ & $\begin{array}{l}\text { Glucose/Water } \\
\text { (G/W) ratio }\end{array}$ \\
\hline Kelulut & & & & & & & $1.03 \pm 0.00^{\mathrm{a}}$ & \\
\hline Gelam & $30.96 \pm 0.03^{\mathrm{ab}}$ & $29.17 \pm 0.03^{\mathrm{ab}}$ & $1.13 \pm 0.04^{\mathrm{b}}$ & $1.48 \pm 0.01^{\mathrm{ab}}$ & $62.74 \pm 0.06^{\mathrm{a}}$ & $60.13 \pm 0.04^{\mathrm{a}}$ & $1.06 \pm 0.00^{\mathrm{b}}$ & $1.63 \pm 0.00^{\mathrm{ab}}$ \\
\hline Wild & & $28.19 \pm 0.05^{b c}$ & $1.28 \pm 0.05^{\mathrm{bc}}$ & $1.36 \pm 0.01^{\mathrm{c}}$ & $63.67 \pm 0.05^{\mathrm{a}}$ & & $1.17 \pm 0.00^{\mathrm{c}}$ & $1.48 \pm 0.00^{\mathrm{c}}$ \\
\hline Pineapple & $32.27 \pm 0.13^{\text {bd }}$ & $27.97 \pm 0.05^{\mathrm{bc}}$ & $1.31 \pm 0.01^{\mathrm{bd}}$ & $1.21 \pm 0.01^{\mathrm{d}}$ & $62.76 \pm 0.13^{\mathrm{a}}$ & $60.24 \pm 0.12^{\mathrm{a}}$ & $1.15 \pm 0.01^{\mathrm{d}}$ & $1.50 \pm 0.00^{\mathrm{cd}}$ \\
\hline Tualang & $31.73 \pm 0.14^{\mathrm{ab}}$ & $28.79 \pm 0.08^{\mathrm{ac}}$ & $1.48 \pm 0.14^{\mathrm{d}}$ & $1.40 \pm 0.06^{\mathrm{bc}}$ & $63.40 \pm 0.26^{\mathrm{a}}$ & $60.52 \pm 0.21^{\mathrm{a}}$ & $1.10 \pm 0.00^{\mathrm{e}}$ & $1.60 \pm 0.01^{\mathrm{bd}}$ \\
\hline Manuka & $34.14 \pm 1.47^{\mathrm{c}}$ & $27.81 \pm 1.20^{\mathrm{c}}$ & $1.32 \pm 0.01^{\mathrm{cd}}$ & $0.90 \pm 0.05^{\mathrm{e}}$ & $64.19 \pm 2.69^{a}$ & $61.97 \pm 2.66^{\mathrm{a}}$ & $1.23 \pm 0.00^{\mathrm{f}}$ & $2.40 \pm 0.10^{\mathrm{e}}$ \\
\hline
\end{tabular}

All values are expressed as mean \pm standard deviation (\%) of three replications. Limit of detection (LOD) of individual sugars are less than or equal to $0.1 \mathrm{~g} / 100 \mathrm{~g}$. The value in the same columns with different superscript lowercase letters were significantly different $(\mathrm{P}<0.05$, ANOVA, Tukey HSD)

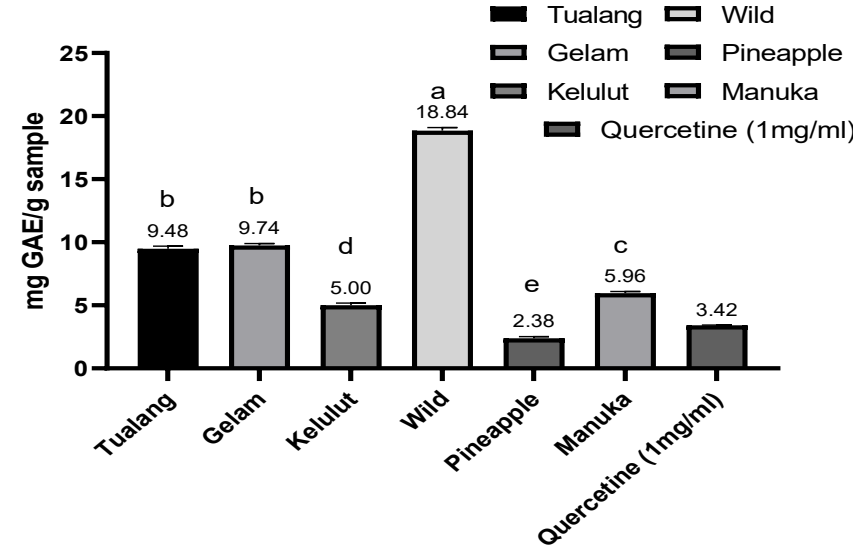

Figure 1. Total phenolic content (TPC) of honey samples and quercetin standard. The TPC was expressed as gallic acid equivalent (mg GAE/g FW). Different letters showed there were significantly different $(\mathrm{P}<0.05$, ANOVA, Tukey's HSD)

Manuka honey had a superior in phenolic content compared to other Malaysian honey, followed by Tualang, Gelam and lastly Borneo honey. The difference of result in the current study with the previous study is probably due to the polyphenol extraction method, different sources of the honey and the storage condition (Khalil et al., 2011).

\subsection{Antioxidant activities}

The antioxidant activities of Malaysian honey and Manuka were determined using DPPH radical scavenging activity and linoleic acid oxidation assay. In principle, the capability of honey samples in donating an electron to stabilized DPPH radical was tested. The result of DPPH radical scavenging activity was expressed in $\mathrm{EC}_{50}(\mathrm{mg} / \mathrm{mL})$, where the minimum amount needed to scavenge $50 \%$ of the DPPH free radical. As shown in Figure 2, Manuka honey showed the lowest $\mathrm{EC}_{50}$ value, followed by Wild, Gelam, Kelulut, Tualang and lastly Pineapple.

This result suggests that phenolic content may not the primary contributor for DPPH radical scavenging activity in Manuka honey. However, it may contribute to

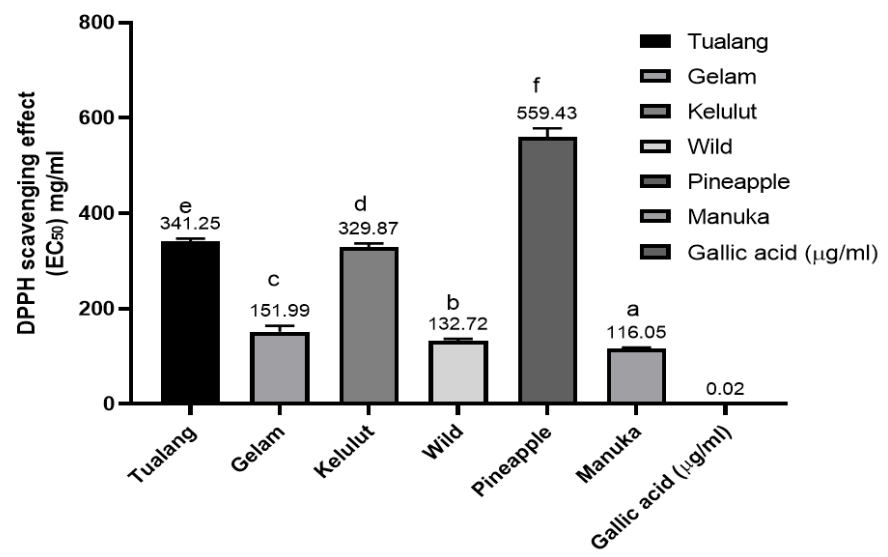

Figure 2. $\mathrm{EC}_{50}$ values of DPPH scavenging effect of honey samples and gallic acid as a standard. Different letters showed there were significantly different $(\mathrm{P}<0.05$, ANOVA, Tukey's HSD)

radical scavenging activity of Malaysian honey, as the result is in line with their total phenolic content (except for Kelulut). Previous study conducted by Kishore et al. (2011) also observed the same trend in Malaysian honey, where they noted the phenolic content and other compounds in the Tualang and Gelam honey may contribute to their DPPH radical scavenging activity.

The antioxidant activities of Malaysian raw honey samples measured using linoleic acid oxidation assay showed the honey samples had a good percentage of protective effect (Figure 3), with Gelam showing the highest percentage of protective activity. However, there was no significant difference $(\mathrm{P}>0.05)$ between Gelam with Wild, Kelulut and Tualang. The result in linoleic acid peroxidation assay indicates that phenolic compounds are not the sole factor that inhibits and protect the system from oxidation. It is well known that honey is rich with vitamins, minerals, proteins and sometimes fats that contain antioxidant properties (Ahmed and Othman, 2013). In addition, the differences in antioxidant activities between the honey samples can also be contributed by the diverse botanical origins (Khalil et al., 2011). 


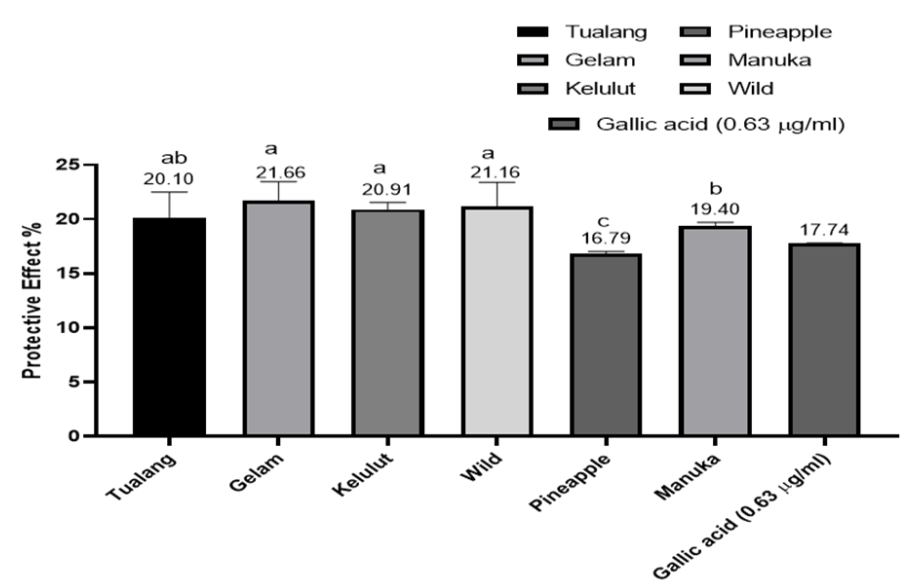

Figure 3. Protective effect (\%) of honey samples and gallic acid standard from lipid peroxidation based on linoleic acid oxidation assay. Different letters showed there were significantly different $(\mathrm{P}<0.05$, ANOVA, Tukey's HSD)

\section{Conclusion}

Collectively, our data showed that Malaysian honeys has an lower level of carbohydrates $(80.27 \%$ to $82.32 \%)$, energy $(324.18 \mathrm{kcal} / 100 \mathrm{~g}$ to $331.20 \mathrm{kcal} / 100$ $\mathrm{g})$, ash $(0.17 \%$ to $0.28 \%)$ and protein $(0.24 \%$ to $0.26 \%$ with exception for Gelam $0.45 \%$ ) but higher in moisture $(17.07 \%$ to $19.08 \%)$ and fat $(0.10 \%$ to $0.36 \%)$ contents compared to Manuka honey. In term of total sugar, no significant differences $(\mathrm{P}>0.05)$ were detected among the honey samples. Nonetheless, all of this result is still within the Codex Alimentarius Commission (2001) guidelines range for floral honey. Overall in term of nutritional value based on comparison with Manuka honey, Kelulut honey is the best (highest energy content, lowest moisture level, fat content and fructose level) among the selected Malaysian honey, while Wild honey has the highest phenolic content and antioxidant properties compared to Manuka honey.

\section{Conflict of interest}

The authors declare no conflict of interest.

\section{Acknowledgement}

The author would like to acknowledge to laboratory staffs at Nutrition lab, UPM for their help and guidance throughout the research.

\section{References}

Adenekan, M.O., Amusa N.A., Okpeze V.E. and Owosibo A.O. (2012). Nutritional and microbiological components of honey samples obtained from Ogun State, Southwestern Nigeria. European Journal of Sustainable Development, 1, 271-286. https://doi.org/10.14207/ ejsd.2012.v1n2p271

Agbagwa, O.E., Otokunefor T.V. and Frank-Peterside N. (2011). Quality assessment of Nigeria honey and Manuka honey. Journal of Microbiology and Biotechnology Research, 1, 20-31.

Ahmed, S. and Othman N.H. (2013). Review of the medicinal effects of Tualang honey and a comparison with Manuka honey. Malaysian Journal of Medical Sciences, 20(3), 6-13.

Ajani, O.O. (2009). Physical characterisation of some honey samples from North-Central Nigeria. International Journal of Physical Sciences, 4(9), 464-470.

Andrada, A.C. and Tellería M.C. (2005). Pollen collected by honey bees (Apis mellifera L.) from south of Caldén district (Argentina): Botanical origin and protein content. Grana, 44(2), 115-122. https:// doi.org/10.1080/00173130510010459

AOAC International. (2005). Official Methods of Analysis. 11th ed. Gaithersburg, USA: AOAC International.

Blasa, M., Candiracci, M., Accorsi, A., Piacentini, M.P., Albertini, M.C. and Piatti, E. (2006). Raw Millefiori honey is packed full of antioxidants. Food Chemistry, 97(2), 217-222. https://doi.org/10.1016/ j.foodchem.2005.03.039

Bogdanov, S., Jurendic, T., Sieber, R. and Gallmann, P. (2008). Honey for nutrition and health: a review. Journal of the American College of Nutrition, 27(6), 677-689. https:// doi.org/10.1080/07315724.2008.10719745

Bogdanov, S. (2016). Honey as nutrient and functional food: A review. Bee Product Science, 1-31. Retrieved from website: http://www.beehexagon.net/data/ documents/8HoneyNutrientFunctionalReview.pdf

Buba, F., Gidado, A. and Shugaba, A. (2013). Analysis of Biochemical Composition of Honey Samples from North-East Nigeria. Biochemistry and Analytical Biochemistry, 2(3), 1-7. https:// doi.org/10.4172/2161-1009.1000139

Chirife, J., Zamora, M.C. and Motto, A. (2006). The correlation between water activity and moisture in honey: Fundamental aspects and application to Argentine honeys. Journal of Food Engineering, 72 (3), 287-292. https://doi.org/10.1016/ j.jfoodeng.2004.12.009

Chua, L.S. and Adnan, N.A. (2014). Biochemical and nutritional components of selected honey samples. Acta Scientiarum Polonorum Technologia Alimentaria, 13(2), 169-179. https:// doi.org/10.17306/J.AFS.2014.2.6 
Codex Alimentarius Commission. (2001). Codex Standard for Honey. Codex Stan 12-1981. Rome, Italy: FAO.

Consumers Association of Penang. (2011). Malaysians Are the 8th Largest Sugar Consumers in the World. Retrieved from Consumers Association of Penang website: http://www.consumer.org.my/index.php/ food/diseases/161-malaysians-are-the-8t $h$ largest-sugar-consumers-in-the-world.

Finola, M.S., Lasagno, M.C. and Marioli, J.M. (2007). Microbiological and chemical characterization of honeys from central Argentina. Food Chemistry, 100 (4), 1649-1653. https://doi.org/10.1016/ j.foodchem.2005.12.046

Food and Agriculture Organization. (2015). Chapter 2: Methods of Food Analysis. Retrieved from FAO website: http://www.fao.org/docrep/006/y5022e/ y5022e03.htm.

Institute for Public Health. (2011). National Health and Morbidity Survey 2011. Vol. 2. Malaysia: Ministry of Health, Malaysia.

Jaafar, M.H.M., Hamid, K.A., Anuar, N., Zohdi, R.M. and Effendi, T.J.B. (2012). Physicochemical properties and pharmacokinetic profiles of selected Malaysian honey, presented at 2012 IEEE Symposium on Business, Engineering and Industrial Applications, September 23-26, 2012., p. 140-145. Bandung, Indonesia: IEEE.

Kamal, M.A. and Klein, P. (2011). Determination of sugars in honey by liquid chromatography. Saudi Journal of Biological Sciences, 18(1), 17-21. https:// doi.org/10.1016/j.sjbs.2010.09.003

Kek, S.P., Chin, N.L., Tan, S.W., Yusof, Y.A. and Chua, L.S. (2017). Classification of Honey from Its Bee Origin via Chemical Profiles and Mineral Content. Food Analytical Methods, 10(1), 19-30. https:// doi.org/10.1007/s12161-016-0544-0

Khalil, M.I., Alam, N., Moniruzzaman, M., Sulaiman, S.A. and Gan, S.H. (2011). Phenolic acid composition and antioxidant properties of Malaysian honeys. Journal of Food Science, 76(6), C921-928. https://doi.org/10.1111/j.1750-3841.2011.02282.x

Khoo, H.E., Azlan, A., Ismail, A. and Abas, F. (2012). Influence of different extraction media on phenolic contents and antioxidant capacity of defatted dabai (Canarium odontophyllum) fruit. Food Analytical Methods, 5(3), 339-350. https://doi.org/10.1007/ s12161-011-9250-0

Khoo, H.E., Azlan, A., Nurulhuda, M.H., Ismail, A., Abas, F., Hamid, M. and Roowi, S. (2013). Antioxidative and cardioprotective properties of anthocyanins from defatted dabai extracts. Evidence-
Based Complementary and Alternative Medicine, 2013, 1-13. https://doi.org/10.1155/2013/434057

Kishore, R.K., Halim, A.S., Syazana, M.S. and Sirajudeen, K.N. (2011). Tualang honey has higher phenolic content and greater radical scavenging activity compared with other honey sources. Nutrition Research, 31(4), 322-325. https:// doi.org/10.1016/j.nutres.2011.03.001

Moniruzzaman, M., Khalil, M.I., Sulaiman, S.A. and Gan, S.H. (2013). Physicochemical and antioxidant properties of Malaysian honey produced by Apis cerana, Apis dorsata and Apis mellifera. BMC complementary and alternative medicine, 13(1), 43. https://doi.org/10.1186/1472-6882-13-43

Murray, S.S., Schoeninger, M.J., Bunn, H.T., Pickering, T.R. and Marlett, J.A. (2001). Nutritional composition of some wild plant foods and honey used by Hadza foragers of Tanzania. Journal of Food Composition and Analysis, 14(1), 3-13. https:// doi.org/10.1006/jfca.2000.0960

National Honey Board. (2015). Honey and Nutrition Information. Retrieved from National Honey Board website: http://www.honey.com/honey-at-home/ honey-nutrition-information.

Singh, N. and Bath, P.K. (1997). Quality evaluation of different types of Indian honey. Food Chemistry, 58 (1), 129-133. https://doi.org/10.1016/S0308-8146 (96)00231-2

Somerville, D. (2005). Fat bees, skinny bees: a manual on honey bee nutrition for beekeepers. Australia: Australian Government, Rural industries research and development corporation.

Tan, S.T., Holland, P.T., Wilkins, A.L. and Molan, P.C. (1988). Extractives from New Zealand honeys. 1. White clover, manuka and kanuka unifloral honeys. Journal of Agricultural and Food Chemistry, 36(3), 453-460. https://doi.org/10.1021/ jf00081a012

Vit, P., Bogdanov, S. and Kilchenmann, V. (1994). Composition of Venezuelan honeys from stingless bees (Apidae: Meliponinae) and Apis mellifera L. Apidologie, 25, 278-288. https://doi.org/10.1051/ apido:19940302

White, J.W. and Doner. L.W. (1980). Honey composition and properties. In Science and Education Administration, US. Beekeeping in the United States Agriculture Handbook No., p. 335, 8291. United States: Department of Agriculture

Whitney, E.N. and Rolfes, S.R. (2008). Understanding Nutrition. $14^{\text {th }}$ ed. United States: Cengage Learning

Yen, G.-C., Duh, P.-D. and Chuang, D.-Y. (2000). Antioxidant activity of anthraquinones and 
anthrone. Food Chemistry, 70(4), 437-441. https:// doi.org/10.1016/S0308-8146(00)00108-4

Zafar, A., Safdar, M.N., Siddiqui, N., Mumtaz, A., Hameed, T. and Sial. M.U. (2008). Chemical analysis and sensory evaluation of branded honey collected from Islamabad and Rawalpindi market. Pakistan Journal of Agricultural Research, 21(1-4), 86-91. 